\title{
Congenital Varicella Zoster Infection
}

National Cancer Institute

\section{Source}

National Cancer Institute. Congenital Varicella Zoster Infection. NCI Thesaurus. Code C116799.

An infection, characterized by the rash of chickenpox or shingles, that is caused by the varicella-zoster virus transmitted directly from the mother to the fetus or neonate during late pregnancy or childbirth. 